Working Paper No. 571, 2002

The Impact of Macroeconomic Variables on Corporate Performance What Shareholders Ought to Know?

by Lars Oxelheim

IUI, The Research Institute of Industrial Economics

P.O. Box 5501

SE-114 85 Stockholm

Sweden 


\title{
The Impact of Macroeconomic Variables on Corporate Performance - What Shareholders Ought to Know?
}

Lars Oxelheim, professor at the Lund Institute for Economic Research, Lund University, Box 7080,22007 Lund, e-mail Lars.Oxelheim@fek.lu.se and at the Research Institute of Industrial Economics (IFN), Box 55665, 10215 Stockholm, e-mail Lars.Oxelheim@ifn.se.

\begin{abstract}
Increased integration and growing macroeconomic fluctuations require more attention to be paid to the link between the "noise" that these fluctuations represent and the company's own development. For many reasons management must weed out the effects of the "noise" so as to obtain a clear picture of the long-term sustainable profits, and thus a picture of how the company's intrinsic competitiveness is fostered. An understanding of the effects of the fluctuations also provides the basis for risk assessment. How far, then, should this "new" view of corporate performance be extended to outsider shareholders? Current reporting practice does not provide these shareholders with an adequate idea of the character and magnitude of the macroeconomic impact on the company. IAS 1 (rev. 1997) indicates that an improvement in this important area may be in the offing. This paper discusses four different interpretational levels of this standard and what these levels mean in terms of relevant information transmitted to outsider shareholders.
\end{abstract}

JEL classification: M41, M20, M21, D81

Key words: External reporting, corporate performance, macroeconomic fluctuations, MUST-analysis

Acknowledgements: Financial support from the Saving Banking Foundation Skåne, Sweden, is gratefully acknowledged. 


\section{The Impact of Macroeconomic Variables on Corporate Performance - What Shareholders Ought to Know?}

As the world's equity markets have become increasingly integrated, and since the different countries have tended to develop their reporting practices independently of one another, there is now a pressing need to bridge the international information gap. The search for a common, cross-border body of reporting rules and the co-ordination of practices, have both become issues of international concern.

Over the last three decades there has been an intensive debate about the kind of information that companies should be obliged to release. Without becoming too involved in this sensitive debate in accounting research we need only note here the two essentials: information of predictive value for assessing a firm's prospects and risks, and information allowing for control, taxation and evaluation ex post. Further, the information should enable inter-temporal comparisons for an individual company as well as across companies (benchmarking) and national borders. This paper emphasizes a particular kind of information, that is to say information about the effects on the firm of a turbulent macroeconomic environment. The macroeconomic environment of the firm is viewed here, along the lines suggested by Oxelheim and Wihlborg (1987), as constituted by a set of four relative prices: exchange rates, interest rates, inflation rates and political risk premiums ${ }^{1}$.

Given the increased financial and economic integration that prevails today, no firm can claim any longer to be unaffected by what is happening on the global economic arena. Even so, today's external reporting is not geared to indicating the extent to which profits are generated by fluctuations in the company's macroeconomic environment during the reporting period. Without that information the outsider shareholders have no chance of figuring out what has happened to the sustainable profits and thus to the firm's intrinsic competitiveness. Consequently, as regards the effects of a volatile macroeconomic environment, current accounting practice is failing to achieve one of the fundamental goals of external reporting

\footnotetext{
${ }^{1}$ The political risk premium refers to the premium charged by the company for the uncertainty about the rules of the market game.
} 
satisfactorily, that is to provide information for control purposes to shareholders and other stakeholders. Moreover, although the international-standard setting bodies support the notion of "decision-relevance" for shareholders no real progress has been made when it comes to achieving the other fundamental goal of external reporting, namely to provide outsider shareholders with information about the future prospects of a company. However, the contents of the IAS 1 issued by the International Accounting Standards Committee (IASC) - revised in 1997 and effective for reporting periods from 1 July 1998 - suggests that a shift in this direction may be on the way. ${ }^{2}$

Extensive efforts over time to create accounting standards or improved practice for the reporting of macroeconomic influences have fallen short of achievement for many reasons. A common denominator in the criticism of these efforts is their lack of focus on corporate performance and competitiveness. Accounting for the effect of a changing macroeconomic environment is static and partial. It is partial since it ignores the interrelation between the macroeconomic variables in question. It is also partial since it only recognizes the effects of items denominated in foreign currencies. Moreover, volume effects due to changing exchange and interests rates are ignored, fuelling the criticism that it is both partial and static. A comprehensive approach calls for the simultaneous consideration of effects caused by changes in all these variables at home and abroad. Having said this, the relevant questions boil down to the availability today of relevant tools for management to produce this kind of information.

In the research literature on exposure management, as opposed to that on accounting, it is recognized that exchange rates are correlated with other macroeconomic variables, and that this should be taken into account when measuring and dealing with exchange rate exposure (see. e.g. Cornell, 1980; Adler and Dumas, 1983; Hekman, 1985; Oxelheim and Wihlborg, 1987). The MUST (Macroeconomic Uncertainty Strategy) - analysis, developed as a management tool and reported elsewhere (see Oxelheim and Wihlborg, 1997), is built on a full recognition of the interdependence between macroeconomic variables constituting the macroeconomic environment of the firm. This approach generates an output that, if passed on

\footnotetext{
${ }^{2}$ Moreover, the usefulness of separating business risk from macroeconomic risk is further underlined by the fact that a number of countries have already or will soon issue regulations concerning business risks and their disclosure (IFAC, 1999). Assuming that the different standard-setting bodies' demand reflects that of different categories of stakeholders of firms, there is obviously a broad interest in an improved quality of information releases.
} 
to the outside shareholder, should mean an improvement on all the issues of the criticism raised above. Hence, the existence of a comprehensive management model for how to deal with effects stemming from the macroeconomic environment should make it possible for companies to improve their information release.

The purpose of this paper is to discuss the reasons why the corporate supply of relevant information on the impact of macroeconomic fluctuation does not meet the demand by outsider shareholders and financial analysts for such information. On the "supply-side", technical barriers associated with such things as the extent to which the output of the MUSTanalysis lends itself for publication, will be discussed below together with political barriers. Will IAS 1 (rev. 1997), given the "right" interpretation and implementation, enhance the outsider shareholders' understanding of the impact of macroeconomic fluctuations on the company's performance and their recognition of the magnitude of macroeconomic risks in essential respects? Finally, in order to assess the magnitude of the political barriers to a full implementation, the corporate response to the "recommendation" within this standard will be analyzed.

The paper is organized as follows. The next section addresses efforts to create a global accounting standard for the impact of a volatile macroeconomic environment on corporate performance and why these have fallen short of achievement. Alternative interpretations of IAS 1 (rev. 1997) are also suggested in this section. There then follows a brief presentation of a multivariate framework (the MUST-analysis) whereby the corporation can measure the impact of macroeconomic fluctuations on its own performance and, hence, its prospects of achieving high-quality information in its reporting. Then comes a section in which the current reporting practices in two global industries are compared with the recommendations of IAS 1 (rev. 1997). The way the result of the multivariate exposure framework should be reported to outsider shareholders is then illustrated, along the lines suggested by IAS 1 (rev.1997). Technical and political implementation aspects are discussed in the concluding section.

\section{Efforts to Create Standards}


Since 1973 and the breakdown of the Bretton Woods agreement a good deal of effort has been spent on thinking about ways of reporting effects assumed to have been caused by the different variables that constitute the macroeconomic environment of the firm. The relative weights allotted to the different variables in the research literature have changed over time. Below is a brief review of how the four categories of variables previously mentioned have been discussed in contemporary research.

In the mid-1970s the increasing volatility in exchange rates triggered an intensive debate about how to report the effects of changing exchange rates. The debate focused on two issues: methods for evaluating foreign assets and liabilities in individual companies, and methods to use when a foreign entity was to be consolidated with the group account. A key document in that debate was Standard No. 8 issued by the Financial Accounting Standards Board (SFAS 8, 1975), which was followed by SFAS 52 (1981). Dukes (1978), Evans, Folks and Jilling (1978), Jilling (1979) and Shanks, Dillard and Murdoch (1979) enriched the debate with empirical evidence about the economic and behavioral impact of SFAS 8. Concurrent recommendations were issued by the Accounting Standard Committee (ASC); Exposure Drafts 18 (1976), 21 (1977) and 27 (1980). Of vital importance at that time were also the recommendations published by the Canadian Institute of Chartered Accountants (CICA) in 1978, 1982 and 1983 and by the International Accounting Standards Committee (IASC) in 1982 and 1983. Different aspects of the two topics have been dealt with by Aliber and Stickney (1975), Beaver and Wolfson (1982) Huefner, Ketz and Largay (1989), McNown and Wallace (1989), Mahdavi and Zhou (1994), Makar, Stanko and Zeller (1996) and Ziebart and Choi (1996) among others. Which methods are to be preferred is still in dispute. In the 1990s a third topic has attracted much attention, namely the reporting concerning financial instruments. Recommendations concerning this issue are formulated in for example SFAS 133, IAS 32 and IAS 39.

The accounting for exchange rate fluctuation has over time focused on the conversion of assets, liabilities and cash flows outside the home jurisdiction. Hence, implicitly this means the focus has been on the effects of nominal exchange rate changes. The unresolved issues concern the inclusion of effects of real exchange rate changes and an increased recognition of competitive exposure (Oxelheim and Wihlborg, 1991). At the beginning of the 2000s, the typical way of reporting the effects of exchange rate fluctuations on performance is to report 
the difference between the actual and a benchmark performance derived under the assumption of unchanged exchange rates.

The impact of other macroeconomic price variables (interest rate, inflation rate and political risk) is covered in the literature in a similar way. The inflationary aspect in accounting research is dealt with primarily by two different approaches. One strand of literature that was particularly influential during the 1970s emphasized the inflationary effects generated within the country. The focus was then on general price-level statements (see e.g. Ijiri, 1976, Staubus, 1976 and Vickrey, 1976). One particular issue here concerned the appropriateness of using the general price level rather than a specific price level (see e.g. Rosenfeld, 1972 and Sterling, 1975). Another group of researchers emphasized the choice of an appropriate price index (see e.g. Bromwich, 1975 and Staubus, 1975). A third issue that recaptured attention in the 1970s (its origins can be traced back to the late 1920s and to names like Sweeney, 1927, and Schmidt, 1930) was current cost accounting (see e.g. Bromwich, 1977; Kennedy, 1978; Prakash and Sunder, 1979; Samuelson, 1980, and Westwick, 1980).

The other strand of the literature on inflation accounting is closely linked to the problem of foreign investments and is concerned with the differences in inflation between the countries in question. It focuses on the purchasing power parity relationship and whether the methods used in accounting give a satisfactory picture of that relationship (see e.g. Aliber and Stickney, 1975; Beaver and Wolfson, 1982; Makar, Stanko and Zeller, 1996, and Ziebart and Choi, 1996). The body of literature in this area, as in the case of the exchange rate area, still lacks consensus as regards the methods to be preferred.

In accounting for interest rate fluctuations there are two main traditions. The first is concerned with debt, and its main focus is on the translation of foreign debt. Any deviations that occur are seen as related to differences in the exchange rate and/or in the interest rates in the countries concerned. These questions are interrelated and are often dealt with simultaneously, albeit implicitly rather than explicitly (see e.g. Oxelheim, 1983). The other tradition is concerned with accounting for financial instruments as defined in SFAS 133 and IAS 39, although the question of risk may not be relevant in the case of all the instruments covered by these recommendations (see e.g. Francis 1990; Bierman, Johnson and Peterson, 1991, and Miltz and Sercu, 1993). At the beginning of the 2000s, the typical way of reporting the effects 
of interest rate fluctuations on performance is to report effects on the financial side only. The effects of these changes on commercial exposure and overall performance are entirely ignored.

The subject of political risk is not covered very adequately in accounting literature as a whole. Some studies investigate firms exposed to sudden increases in product price and the accounting actions that ensue (see e.g. Watts and Zimmerman, 1986, and Han and Wang, 1998). The effect generated by the realization of a political risk is often treated in accounting as an extraordinary item. Several studies have shown the problem in using "extraordinary items" in this context as an instrument for the smoothing out of income (see e.g. Barnea, Roden and Sadan, 1975; Craig and Walsh, 1989; Walsh, Craig and Clark, 1991, and Dempsey, Hunt and Schroeder, 1993). However, these studies have not dealt appropriately with the effects of political risk on a firm's performance. Rather, they have shown how the accounting system is used in a creative way when it comes to absorbing the effects caused by a political risk that has materialized.

Overall, then, attempts to create a standard, or standards, to account for the macroeconomic influence on the firm justify the criticism raised in the introduction of this article. However, IAS 1, Presentation of Financial Statements (rev. 1997) does represent a step forward in this respect. It applies to all types of company with a profit goal, including banks and insurance companies (for which further requirements are specified in IAS 30, Disclosure in the Financial Statements of Banks and Similar Financial Institutions). IAS 1 contains the following formulation as paragraph 8 under the heading, "Components of Financial Statements":

Enterprises are encouraged to present, outside of the financial statements, a financial review by management which describes and explains the main features of the enterprise's financial performance and financial position and the principal uncertainties it faces. Such a report may include a review of:

(a) the main factors and influences determining performance, including changes in the environment in which the enterprise operates, the enterprise's response to those changes and their main effect, and the enterprise's policy for investment to maintain 
and enhance performance, including its dividend policy;

(b) the enterprise's sources of funding, the policy on gearing and its risk management policies; and

(c) the strength and resources of the enterprise whose value is not reflected in the balance sheet under International Accounting Standards.

It is paragraph 8 that marks a move toward information-channeling as appropriate for scenario analysis and risk assessment, including profit-filtering for historical performance analysis and control as well. The standard as a whole recommends the minimal requirements regarding the content of reporting. Financial information of an interim character is not included.

The standard may be seen as a compromise, and in this capacity it has a very loose framework. Environment can be given different interpretations. Here it is interpreted as macroeconomic environment. Factors and influences are interpreted as macroeconomic variables with an impact on the corporate profit capacity (performance) in product, service and financial markets, i.e. currencies, interest rates and consumer/producer prices. The enterprise's response to those changes and their main effect can be expressed in many ways. To be useful for control purposes and to be applicable in a forward-looking manner, it should be aimed here at measurement in the form of sensitivity coefficients, i.e. a measurement of the change in a company's profit as a consequence of a change in each and every one of the most important macroeconomic variables. Risk management policies under 8(b) should, in line with earlier interpretations, pertain to strategies for how the company is handled with respect to the above-mentioned variables and the possibility of changes in this respect during the next reporting period. Here the company is expected to provide information about the type and extent of different hedging operations as response to macroeconomic uncertainty.

IAS 1 (rev.1997) provides no explicit requirement for a uniform analysis and quantification, which opens up for a variety of responses to its paragraph $8(a-b)$. One alternative here is to separate two categories: non-quantitative responses (1-2, below) and quantitative responses (3-4, below). Although it opens up for some discretion, the following four categories are used in order to extract additional insight into the current status of corporate reporting: 
1) no specification of the variables, no measurement or strategies as named above, i.e. paragraph $8(a-b)$ is not considered.

2) the giving of variables, measurements and strategies in general terms but without much detailed specification, i.e. the reporting continues in the way that is most common today. "The results for the period have been influenced negatively by currency fluctuations" or "the lower interest levels have had a positive influence on the result" are typical examples of wording under this alternative.

3) the giving of some but not all information about the most significant variables, the magnitude of the influence and the appropriate strategies for handling these variables. This alternative, involving a certain amount of information, undeniably comprises a step in the right direction, in so far as the information provided is correct. However, if only one coefficient is given, for example, to live up to the standard of being correct it should have been estimated by considering its relationship to the other non-given relevant variables. And even if the information is correct, this alternative still means that the information is insufficient as a basis for weeding out noise of historic profits and assessing the prospects of the company.

4) a complete specification of the most significant macroeconomic variables, of the sensitivity coefficients for these variables estimated within a multivariate framework, and of the company's strategy for handling fluctuations in these variables over the past period and in the future. An information release that is congruent with the information content of the output of the MUST-analysis briefly described in the next section.

We concentrate here on IAS 1 (rev. 1997), while remaining well aware of the forces at work in the interplay between IASC and other key actors in the standard-setting arena - forces that should be considered once causality as regards the development in accounting is discussed.

\section{A Comprehensive Approach to Assessing the Impact of Macroeconomic Fluctuations on the Firm}


If there is to be anything informative to report about the impact of macroeconomic variables on corporate performance it is necessary that the company has made and continues to make systematic analyses of this impact. Powerful outside forces - of which the one exerted by financial analysts may be the strongest - should be at work to increase management's interest in answers to the important question of how far the profits of the company are due to the quality of the product or service and how far they stem from changes in the macroeconomic environment. The need to sort these things out is evident in the choice of strategy, in discussing bonuses or in the evaluation of subsidiary managers. By filtering out the (temporary) macroeconomic "noise" from corporate profits as a first step, a picture is obtained of the "sustainable" profits, i.e. a measure of the company's competitiveness. After this filtering, an apparently favorable result may thus be transformed into a strong signal about reduced competitiveness, i.e. to a "leading indicator" regarding the need to develop the product/service and/or production process. Or, vice versa, i.e. in the case of an unfavorable result. Step two is the formulation of a risk management strategy, i.e. whether the company should handle the risks generated by future macroeconomic fluctuations, and if so how. For companies that handle steps one and two intelligently, step three means that there is something valuable to communicate to the outsider shareholders of the firm.

The central concept in this article is that the vulnerability of a company to changes in its macroeconomic environment can be expressed by measures of sensitivity to changes in the relative prices of three categories - exchange rates, interest rates, and inflation rates. The choice of these categories of macroeconomic variable is not ad hoc but is derived from international equilibrium relationships (see e.g. Aliber and Stickney, 1975; Dufey and Srinivasulu, 1983; Oxelheim and Wihlborg, 1987). The relative prices contained in these relationships are reflections of macroeconomic shocks or disturbances involving changes in GDP, aggregate demand, monetary policy and other macroeconomic variables. One option is to study in a direct way the vulnerability of corporate performance to macroeconomic shocks. However, as opposed to the fundamental shocks, the relative prices have the great advantage of being easily observable at all times. In addition, the relationship between a fundamental shock and the relative prices may be unstable due to policy regime shifts whereas the relationship between the relative prices and the performance of the firm is fairly stable and directly reflects the competitive situation. 
One of the equilibrium relationships is purchasing power parity (PPP), which is based on variables from two of the categories: the nominal exchange rate and relative inflation. Deviations $^{3}$ from PPP generate excess profits or losses on the commercial side of the individual firm. In case of a deviation of the home country currency in the form of an overvaluation (undervaluation) we can compare the effect of this with a tax (subsidy) of comparable magnitude on home country production vis-á-vis production abroad. ${ }^{4}$ The other equilibrium relationship is the international Fisher effect (IFE), which in addition to the nominal exchange rate contains the third category of macroeconomic price variable, i.e. the interest rate. Deviations from IFE cause excess profits or losses on the financial side of the individual firm. ${ }^{5}$ However, interest rate changes may also impact the commercial side of the firm, e.g. through their influence on the demand for capital goods. In addition, political risk expresses itself as the need for a re-estimation of the sensitivity coefficients for the three categories. It then remains for the individual firm to determine which variables are the most

\section{Figure 1 Components of a MUST-analysis}

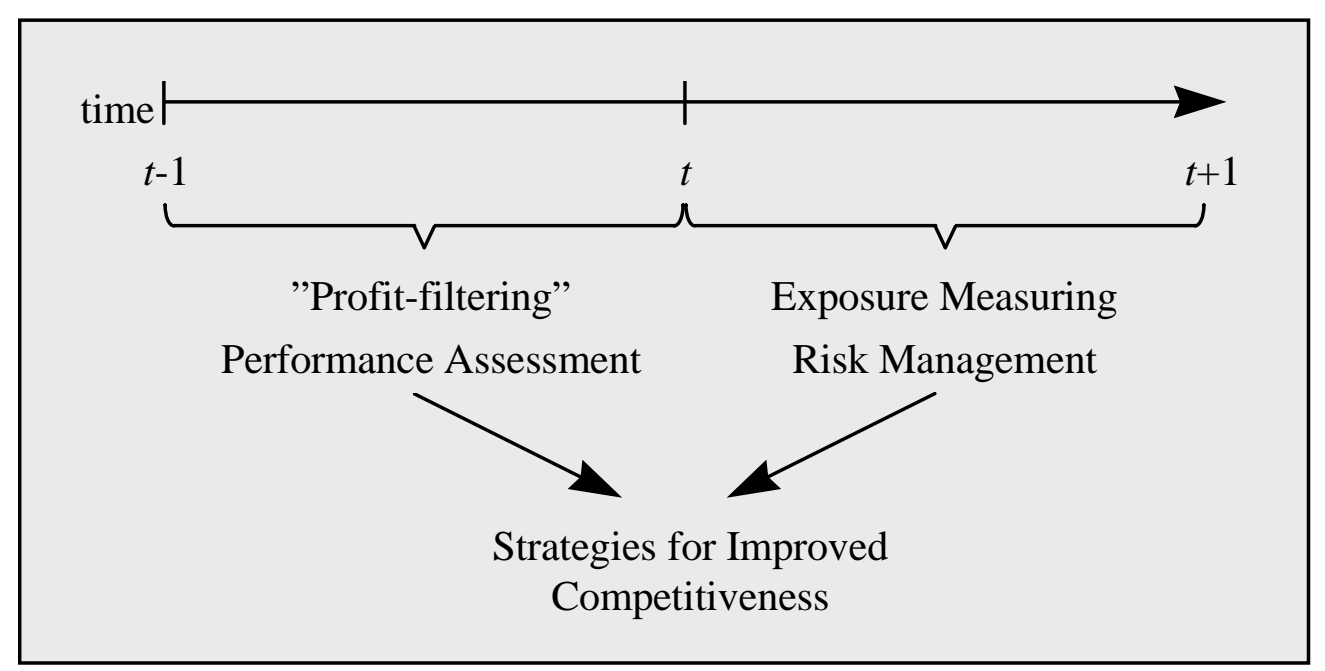

Source: Oxelheim and Wihlborg (1997)

influential within each category.

\footnotetext{
${ }^{3}$ In the analysis of the "true" performance, changes in the magnitude of period-to-period deviations from PPP and IFE need to be measured. By focusing on changes rather than levels the problem of determining long-term equilibrium exchange rates, interest rates and inflations rates is circumvented.

${ }^{4}$ Where the location of foreign production reflects the weights in the PPP calculation.

5 Expectations play a key role in PPP and IFE. "Deviation" and "excess" then become relative terms.
} 
The need for "filtering" calls for a set of sensitivity coefficients determined within a multivariate framework. The MUST-analysis represents such a framework for the company to estimate sensitivity coefficients and to carry out steps one and two (see Figure 1). It offers a basis for: 1) identifying the macroeconomic variables that are most important to the particular company, 2) determining the effect on performance generated by fluctuations in these variables, and 3) formulating a suitable strategy for handling these variables. Moreover it can be routinized since it demands only regression programs offered as standard equipment to most computers.

The MUST- analysis starts with a fundamental analysis of variables with potential explanatory value. A broad and complete specification of relevant variables is instrumental to a robust inference. The identification of the most important macroeconomic variables from this set of variables then involves the use of multivariate regression analysis. Stepwise regression with a backward elimination procedure is used to reduce the number of explanatory variables, which explain a satisfactorily large part of the variation in the performance variable $^{6}$. As opposed to traditional approaches, the MUST-analysis acknowledges the interdependence between different kinds of macroeconomic variables. The basic assumption is that the interdependence between exchange rates, interest rates, and inflation rates is neither too strong so as to create multicollinearity, nor so weak that the measuring of each variable separately is acceptable.

The MUST-analysis is built on a multivariate linear regression framework that has its limitations. For instance, the linear relationship between cash flows and macroeconomic factors can be made questionable if the firm has opportunities to exercise real options like switching suppliers, location of production, or marketing efforts from one country to another. However, considering the cost of switching, the linear relationship should be seen as a good approximation in the short to medium perspective with not-too-big macroeconomic changes making the company pass the "trigger level" for switching (Dixit and Pindyck, 1994, and Capel, 1997).

\footnotetext{
${ }^{6}$ In order to limit the risk of specification bias and to evaluate the "robustness" of the statistical inference, the analysis could be extended to include an Extreme Bound Analysis (see e.g. Durham, 2001).
} 
An application of a multivariate estimation of sensitivity coefficients in the Swedish car manufacturer Volvo Cars (now Ford-owned), will serve as an illustration. Prior to the regression analysis, a fundamental analysis is needed to identify variables with potential economic explanatory power. The questions to be asked in such an analysis are: where is Volvo Cars' production located; who are Volvo Cars' major competitors and where is their production; where do Volvo Cars buy inputs from and where do Volvo Cars' competitors buy their inputs from; and finally, where are Volvo Cars' major geographical markets? Whenever financial cash flows are involved an additional question is: what are the major currencies among Volvo Cars' financial positions? For the period 1981-1990, the answers to these questions generated 20 variables with potential explanatory power. For instance, the fact that Volvo Cars' major competitors were located in Germany called for the inclusion of German producer prices, German interest rates and the SEK/DEM exchange rate. The outcome of a subsequent search for the variables with the highest explanatory value among the 20 found for the period 1981-90, using quarterly data, is given in Equation 1.

$$
\begin{aligned}
{\left[\Delta \frac{C F^{S E K}}{P^{S E K}}-E_{t-1}\left(\Delta \frac{C F^{S E K}}{P^{S E K}}\right)\right] } & =-5.6\left[\Delta u^{F C / S E K}-E_{t-1}\left(\Delta u^{F C / S E K}\right)\right] \\
& -0.1\left[\Delta i^{S E K}-E_{t-1}\left(\Delta i^{S E K}\right)\right] \\
& +0.2\left[\Delta i^{\text {world }}-E_{t-1}\left(\Delta i^{\text {world }}\right)\right] \\
& +25.3\left[\Delta \pi^{P P I D E}-E_{t-1}\left(\Delta \pi^{P P I D E}\right)\right]
\end{aligned}
$$

where

$$
\begin{array}{ll}
C F^{S E K} & =\text { Commercial cash flows in SEK } \\
P^{S E K} & =\text { Swedish price level } \\
u^{\text {FC/SEK }} & =\text { Swedish real effective exchange rate (FC/SEK) } \\
i^{S E K} & =\text { Swedish } 3 \text {-month interest rate } \\
i^{\text {world }} & =\text { World short-term interest rate (basket) } \\
\pi^{P P I D E} & =\text { Producer prices in Germany }
\end{array}
$$


and $\Delta$ denotes percentage change between time $t-1$ and $t$. For example, the coefficient -5.6 in the equation means that for the period under investigation the commercial cash flows of Volvo Cars decreased (increased) 5.6 per cent for every percentage point by which the Swedish real effective exchange rate increased (decreased). Producer prices in Germany and interest rates (Swedish short-term as well as a world basket) are other variables that should be regarded as important to the performance of Volvo Cars. The set of relevant variables may shift over time and the company should therefore follow up the process of identification continuously.

The most important market for Volvo Cars at the time of the study was the US market, while a large fraction of inputs were purchased in Germany. Given such a pattern there is a risk that the investor without information support from the company will infer a positive effect from a depreciating krona against the US dollar and a negative effect from a depreciating krona against the Deutschmark. The estimation of an equation containing the most important bilateral exchange rates, however, shows the SEK/DEM exchange rate to be the only significant one, but with a positive sign, implying a positive effect on cash flows from a depreciation of the Swedish krona versus the Deutschmark. This model also includes the German producer prices and Swedish short-term interest rates, where the interest rate coefficient reflects changes of the cost of debt as well as changes in the demand for cars.

The fact that the most important competitors of Volvo Cars are the German carmakers Mercedes (lower end), BMW (lower end), Audi and Volkswagen explains the great importance of variables associated with Germany. The positive effect of a depreciating krona against the Deutschmark should be interpreted as a result of the fact that gains in competitiveness exceed the higher cost of inputs purchased in Germany. The lesson to be learnt from the Volvo Cars case is that the currency denomination of actual cash flows does not necessarily tell the true story of the sensitivity of corporate cash flows. The shareholders as well as the financial analysts need further information from the company to sort such things out. They need information of the kind given in Equation 1. Another lesson of the Volvo Cars case is that the introduction of the euro should not cause any substantial decrease in the demand from shareholders of European based firms of reports about the impact of volatile exchange rates on the performance. 


\section{Current Practice Relative to the Recommendations of IAS 1 (rev. 1997) as to How Macroeconomic Influences on the Firm Should Be Reported}

Data for this article has been collected and analyzed on an annual basis (1985-2000). The data concerns the way companies in different industries and countries report and deal with the impact on their performance of changes in their macroeconomic environment. The annual analysis starts with an examination of the way companies report relevant variables, measures of vulnerability and strategies. A follow-up is also conducted, albeit not reported in detail here, charting the way the companies handle these issues de facto. In this way a picture is obtained of the size of the difference between the information given in the external reports and the actual way these issues are currently viewed in the company. The picture that emerges, which will not be further discussed in this paper, is that companies in general are no more sophisticated in their analysis of the macroeconomic impact than the annual reports reveal. However, the fairly low ambition currently prevailing relative to the more comprehensive approach discussed in the previous section will naturally affect the companies' interpretation of IAS 1 (rev. 1997). Implementation in line with alternative (4) above would, thus, call for considerable adjustments on the part of most companies.

The accounting part of the study is presented in Tables 1 and 2, where the column numbers coincide with the numbering of categories in Section 2. Table 1 contains an analysis of the annual reports of companies in the automotive industry for the fiscal years 1996/97 and $1998 / 1999$, i.e. the years immediately before and after the IAS 1 (rev. 1997) recommendation came into force. Only explicit statements are taken into account in the study, generally consisting of the notes to the financial statements, the CEO's letter to shareholders or statements elsewhere in the annual report. Table 1 provides us with a firm conclusion: as late as 1999 no company in the automotive industry (the study was carried out on a group basis) published information in its external reporting which would enable shareholders to understand the extent of macroeconomic influence on corporate performance. The same conclusions can be drawn from Table 2 as regards the global paper and pulp industry.

To qualify for a listing in Column 4 the company should have provided information in line with the outcome of a multivariate approach of the kind discussed in the previous section. With the help of a multivariate regression technique three to four variables can normally be 
identified as channels for the bulk of the influence on the firm stemming from its macroeconomic environment. Table 1 shows that only one company - Rolls Royce - provided a satisfactory specification regarding the macroeconomic variables that have the most impact on corporate performance. Six out of twenty-four companies made an effort to identify at least some variables, albeit not a complete set according to a multivariate identification procedure. The majority of companies provided sweeping formulations about various categories of macroeconomic variables without pinpointing any specific ones. Hence, apart from arousing a feeling that something could be blamed or thanked, the information they provided had no further value for the shareholder.

When it comes to the magnitude of the impact on corporate performance deriving from the variables that have been identified as relevant, only Scania followed up their partial information with such figures. All the other companies refrained from making a quantitative specification of the impact. They either provided no information at all or referred vaguely to the impact in terms such as big, small or similar.

In 1999 quite a few companies tried to specify their hedging strategies, but the lack of information about the relevant variables and sensitivity coefficients for these greatly reduces the value of any such information. However, also in this respect Scania is an exception. This company comes closest to a useful - albeit not complete - specification of the macroeconomic impact on the firm.

None of the companies, with the possible exception of Scania, provided their shareholders with the chance of seeing what had happened regarding the sustainable profits, i.e. the profits after the macroeconomic noise had been eliminated. There was no possibility for the investors to make any kind of analysis of what would happen to the company, given a development like the Asian crisis, for example.

Annual reports before and after the IAS 1 (rev. 1997) came into force have also been compared. The result shows fairly small changes as regards the pinpointing of relevant macroeconomic variables. Five companies improved their information content and one company went the other way. Only Rolls Royce, however, improved its release in a substantial way that made a difference to the shareholders. In terms of release of exposure 
measures there was no change at all, whereas the propensity to release information on strategies for handling macroeconomic influence on the firm improved substantially. Seven companies improved their information content in this respect. In this case we have thus witnessed a significant improvement (at the 5\% level) for the automotive industry ${ }^{7}$ between 1996/97 and 1998/99. ${ }^{8}$

Table 1 Accounting for macroeconomic influences in the global automotive industry Annual reports 1998/99

\section{(A) Information on macro price variables influencing performance}

\begin{tabular}{|c|c|c|c|}
\hline $\begin{array}{c}1 \\
\text { No information }\end{array}$ & $\begin{array}{c}2 \\
\text { General information } \\
\text { about being affected, } \\
\text { no specification of } \\
\text { individual variables }\end{array}$ & $\begin{array}{c}3 \\
\text { Partial specification } \\
\text { of individual macro- } \\
\text { price variables }\end{array}$ & $\begin{array}{c}4 \\
\text { Complete } \\
\text { specification of } \\
\text { macro-price } \\
\text { variables influencing } \\
\text { performance }\end{array}$ \\
\hline & $\begin{array}{l}\text { Audi (D) } \\
\text { BMW (D) } \\
\text { Daihatsu (JP) } \\
\text { DaimlerChrysler (D) } \\
\text { Fleetwood (US) } \\
\text { GM (US) } \\
\text { Isuzu (JP) } \\
\text { Man (D) } \\
\text { Mazda (JP) } \\
\text { Mitsubishi (JP) } \\
\text { Navistar (US) } \\
\text { Nissan (JP) } \\
\text { Oshkosh (US) } \\
\text { Peugeot (F) } \\
\text { Toyota (JP) } \\
\text { Winnebago (US) } \\
\text { Volkswagen (D) } \\
\end{array}$ & $\begin{array}{l}\text { Ford (US) } \\
\text { Honda (JP) } \\
\text { PACCAR (US) } \\
\text { Renault (F) } \\
\text { Scania (SE) } \\
\text { Volvo (SE) }\end{array}$ & Rolls Royce (UK) \\
\hline
\end{tabular}

\footnotetext{
${ }^{7}$ Due to the merger, Chrysler, Mercedes Benz and Daimler Chrysler are not included in the test.

${ }^{8}$ A McNemar test of the information content before and after July 1, 1998 has been applied under the assumption that the automotive industry can be seen as a representative sample from a "superpopulation". The material has been divided into a $2 \times 2$ matrix with columns $1+2$ representing no valuable information at all and columns $3+4$ information of at least some value to the shareholder.
} 
(B) Exposure measures in annual reports

\begin{tabular}{|l|l|l|l|}
\hline \multicolumn{1}{|c|}{ No information } & \multicolumn{1}{|c|}{$\begin{array}{c}\text { General information } \\
\text { Partial specification } \\
\text { of exposure } \\
\text { measures }\end{array}$} & $\begin{array}{c}\text { 1 } \\
\text { Complete } \\
\text { specification of } \\
\text { exposure measures }\end{array}$ \\
\hline Audi (D) & Saihatsu (JP) & BMW (D) & Fleetwood (US) \\
DaimlerChrysler (D) & Ford (US) & \\
GM (US) & Man (D) & \\
Honda (JP) & Mazda (JP) & & \\
Isuzu (JP) & Oshkosh (US) & \\
Mitsubishi (JP) & PACCAR (US) & & \\
Navistar (US) & Peugeot (F) & & \\
Nissan (JP) & Rolls Royce (UK) & & \\
Renault (F) & Volvo (SE) & & \\
Toyota (JP) & & & \\
Winnebago (US) & & & \\
Volkswagen (D) & & & \\
\hline
\end{tabular}

(C) Publication of information about exposure management strategy

\begin{tabular}{|c|c|c|c|}
\hline $\begin{array}{c}1 \\
\text { No information }\end{array}$ & $\begin{array}{c}2 \\
\text { General information }\end{array}$ & $\begin{array}{c}3 \\
\text { Partial specification } \\
\text { of management } \\
\text { strategy }\end{array}$ & $\begin{array}{c}4 \\
\text { Complete } \\
\text { specification of } \\
\text { management } \\
\text { strategy } \\
\end{array}$ \\
\hline $\begin{array}{l}\text { Daihatsu (JP) } \\
\text { DaimlerChrysler (D) } \\
\text { Fleetwood (US) } \\
\text { Isuzu (JP) } \\
\text { Winnebago (US) }\end{array}$ & $\begin{array}{l}\text { GM (US) } \\
\text { Man (D) } \\
\text { Nissan (JP) } \\
\text { Peugeot (F) } \\
\text { Toyota (JP) } \\
\text { Volkswagen (D) }\end{array}$ & $\begin{array}{l}\text { Audi (D) } \\
\text { BMW (D) } \\
\text { Ford (US) } \\
\text { Honda (JP) } \\
\text { Mazda (JP) } \\
\text { Mitsubishi (JP) } \\
\text { Navistar (US) } \\
\text { Oshkosh (US) } \\
\text { PACCAR (US) } \\
\text { Renault (F) } \\
\text { Rolls Royce (UK) } \\
\text { Scania (SE) } \\
\text { Volvo (SE) }\end{array}$ & \\
\hline
\end{tabular}


Even if we can see some improvement after the IAS 1 (rev. 1997) came into force, it would be going too far, on a basis of this study, to claim that the improvement was due to that. The significant improvements as regards the choice of strategies for handling changes in the macroeconomic environment may rather reflect SFAS 119 and IAS 32 or an early adjustment to SFAS 133 and IAS 39, which regulates accounting for derivatives/instruments and hedging activities in the annual reports. Several of the American companies have mentioned SFAS 133, which was issued in June 1998 and expected to come into force in June 1999 (later deferred one year by SFAS 137). Hence, SFAS 133 may explain some of the moves towards more extensive reporting about choice of strategy that was found in the annual reports for 1998/1999. Another explanation may be found in the response to a stronger demand for information on the part of shareholders, as a result of the uncertainty caused by the contemporary financial crises.

Finally, a cross-industry comparison involving the automotive industry and the paper and pulp industry was carried out. The hypothesis behind the comparison was formulated as a tendency for companies with more heterogeneous products to release more relevant information. The hypothesis was assumed to reflect the delicate balance between supplying outsider shareholders with relevant information, and putting the competitiveness of the firm at risk by supplying competitors with the very same information. However, the paper and pulp industry, characterized by fairly homogeneous products provides no less information than the automotive industry. No statistically significant differences exist between the two distributions. Moreover, neither of the distributions shows any significant pattern as regards the nationality of the reporting firm. 
Table 2 Accounting for macroeconomic influences in the global paper and pulp industry Annual reports 1998/99

(A) Information on macro price variables influencing performance

\begin{tabular}{|c|c|c|c|}
\hline $\begin{array}{c}1 \\
\text { No information }\end{array}$ & $\begin{array}{c}2 \\
\text { General information } \\
\text { about being affected, } \\
\text { no specification of } \\
\text { individual variables }\end{array}$ & $\begin{array}{c}3 \\
\text { Partial specification } \\
\text { of individual macro- } \\
\text { price variables }\end{array}$ & $\begin{array}{c}4 \\
\text { Complete } \\
\text { specification of } \\
\text { macro-price } \\
\text { variables influencing } \\
\text { performance }\end{array}$ \\
\hline & $\begin{array}{l}\text { Amcor (AU) } \\
\text { AssiDomän (S) } \\
\text { Bemis (US) } \\
\text { Boise Cascade (US) } \\
\text { Buhrmann (NL) } \\
\text { Cartiere Burgo (I) } \\
\text { Champion } \\
\text { International (US) } \\
\text { Chesapeake (US) } \\
\text { David S Smith (UK) } \\
\text { Domtar (CA) } \\
\text { Fletcher Challenge } \\
\text { (NZ) } \\
\text { Georgia Pacific (US) } \\
\text { Haindl (D) } \\
\text { Industrieholding Cham } \\
\text { (CH) } \\
\text { Inveresk (IE) } \\
\text { Kimberly Clark (US) } \\
\text { La Rochette (F) } \\
\text { Louisiana Pacific (US) } \\
\text { Mayr-Melnhof (AT) } \\
\text { Mead (US) } \\
\text { Potlatch (US) } \\
\text { Rottneros (S) } \\
\text { Sonoco Products (US) } \\
\text { St Laurent Paperboard } \\
\text { (CA) } \\
\text { Temple-Inland (US) } \\
\text { Westvaco (US) } \\
\text { Weyerhaeuser (US) } \\
\text { Willamette Industries } \\
\text { (US) }\end{array}$ & $\begin{array}{l}\text { Bunzl (UK) } \\
\text { Fort James Corp (US) } \\
\text { Holmen (S) } \\
\text { International Paper } \\
\text { (US) } \\
\text { Norske Skog (N) } \\
\text { Rock-Tenn (US) } \\
\text { Sappi (ZA) } \\
\text { SCA (S) } \\
\text { Tembec (CA) } \\
\text { UPM-Kymmene (F) }\end{array}$ & \\
\hline
\end{tabular}


(B) Exposure measures in annual reports

\begin{tabular}{|c|c|c|c|}
\hline $\begin{array}{c}1 \\
\text { No information }\end{array}$ & $\begin{array}{c}2 \\
\text { General information }\end{array}$ & $\begin{array}{c}3 \\
\text { Partial specification } \\
\text { of exposure } \\
\text { measures }\end{array}$ & $\begin{array}{c}4 \\
\text { Complete } \\
\text { specification of } \\
\text { exposure measures }\end{array}$ \\
\hline $\begin{array}{l}\text { Bemis (US) } \\
\text { Fletcher Challenge } \\
\text { (NZ) } \\
\text { Haindl (D) } \\
\text { Holmen (S) } \\
\text { Industrieholding Cham } \\
\text { (CH) } \\
\text { La Rochette (F) } \\
\text { Louisiana Pacific (US) } \\
\text { Mayr-Melnhof (AT) } \\
\text { Potlatch (US) } \\
\text { Rock-Tenn (US) } \\
\text { Sappi (ZA) } \\
\text { St Laurent Paperboard } \\
\text { (CA) } \\
\text { Westvaco (US) } \\
\text { Willamette Industries } \\
\text { (US) }\end{array}$ & $\begin{array}{l}\text { Amcor (AU) } \\
\text { Boise Cascade (US) } \\
\text { Buhrmann (NL) } \\
\text { Bunzl (UK) } \\
\text { Cartiere Burgo (I) } \\
\text { Champion } \\
\text { International (US) } \\
\text { Chesapeake (US) } \\
\text { David S Smith (UK) } \\
\text { Domtar (CA) } \\
\text { Georgia Pacific (US) } \\
\text { Rottneros (S) } \\
\text { Sonoco Products (US) } \\
\text { Temple-Inland (US) } \\
\text { Weyerhaeuser (US) }\end{array}$ & $\begin{array}{l}\text { AssiDomän (S) } \\
\text { Fort James Corp (US) } \\
\text { International Paper } \\
\text { (US) } \\
\text { Inveresk (IE) } \\
\text { Kimberly Clark (US) } \\
\text { Mead (US) } \\
\text { Norske Skog (N) } \\
\text { SCA (S) } \\
\text { Tembec (CA) } \\
\text { UPM-Kymmene (F) }\end{array}$ & \\
\hline
\end{tabular}

(C) Publication of information about exposure management strategy

\begin{tabular}{|c|c|c|c|}
\hline $\begin{array}{c}1 \\
\text { No information }\end{array}$ & $\begin{array}{c}2 \\
\text { General information }\end{array}$ & $\begin{array}{c}3 \\
\text { Partial specification } \\
\text { of management } \\
\text { strategy }\end{array}$ & $\begin{array}{c}4 \\
\text { Complete } \\
\text { specification of } \\
\text { management } \\
\text { strategy } \\
\end{array}$ \\
\hline $\begin{array}{l}\text { Haindl (D) } \\
\text { La Rochette (F) } \\
\text { Louisiana Pacific (US) } \\
\text { Potlatch (US) } \\
\text { Willamette Industries } \\
\text { (US) }\end{array}$ & $\begin{array}{l}\text { Amcor (AU) } \\
\text { Bemis (US) } \\
\text { Boise Cascade (US) } \\
\text { Buhrmann (NL) } \\
\text { Champion } \\
\text { International (US) } \\
\text { David S Smith (UK) } \\
\text { Domtar (CA) } \\
\text { Fletcher Challenge } \\
\text { (NZ) } \\
\text { Fort James Corp (US) } \\
\text { Georgia Pacific (US) } \\
\text { Industrieholding Cham } \\
\text { (CH) } \\
\text { Inveresk (IE) } \\
\text { Mayr-Melnhof (AT) } \\
\text { Rottneros (S) } \\
\text { Sonoco Products (US) } \\
\text { St Laurent Paperboard } \\
\text { (CA) } \\
\text { Temple-Inland (US) } \\
\text { Westvaco (US) }\end{array}$ & $\begin{array}{l}\text { AssiDomän (S) } \\
\text { Bunzl (UK) } \\
\text { Cartiere Burgo (I) } \\
\text { Chesapeake (US) } \\
\text { Holmen (S) } \\
\text { International Paper } \\
\text { (US) } \\
\text { Kimberly Clark (US) } \\
\text { Mead (US) } \\
\text { Norske Skog (N) } \\
\text { Rock-Tenn (US) } \\
\text { Sappi (ZA) } \\
\text { SCA (S) } \\
\text { Tembec (CA) } \\
\text { UPM-Kymmene (F) }\end{array}$ & \\
\hline
\end{tabular}




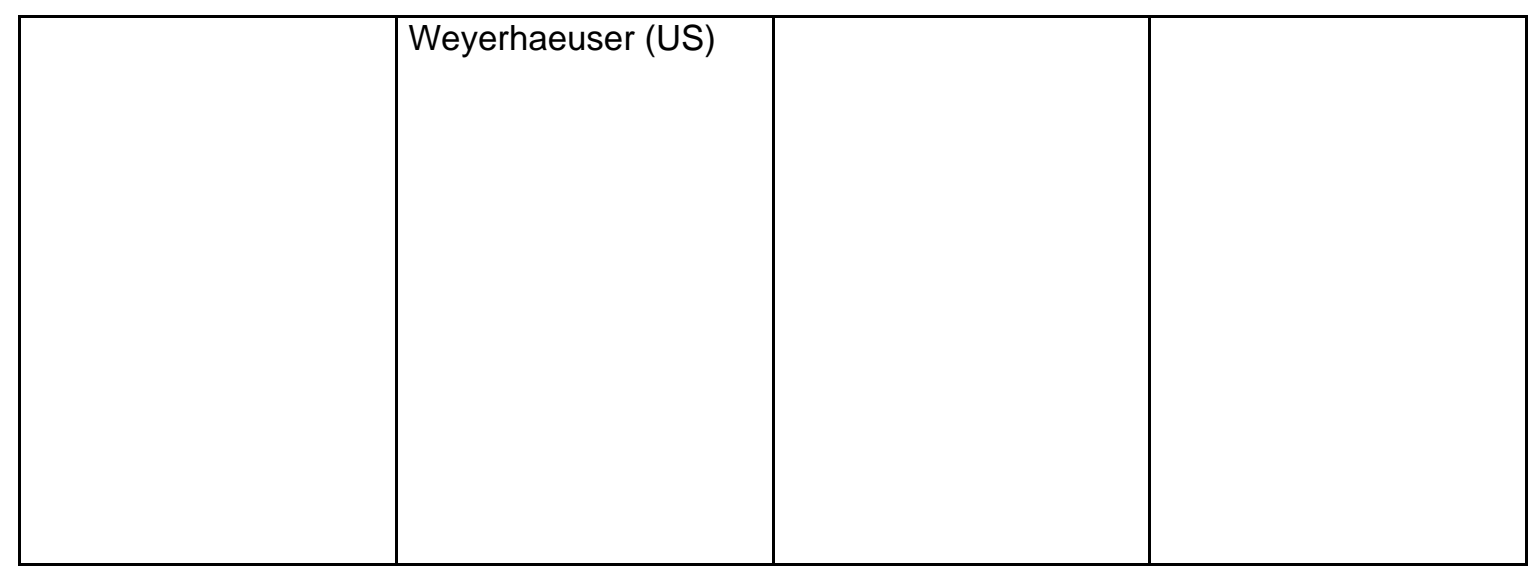

\section{Illustration of an Information Release that Satisfies the Demands of the Outsider Shareholder}

What, then, should the information release look like in order to meet the demands of the outsider shareholders as expressed in their desire to evaluate the company's strategy and performance in an adequate way? The information content of the release suggested here should present the well-managed firm with no extra processing work. Rather, it should be seen as a subset or lower threshold for what should be able to be used as relevant decision support by the company's own management and board of directors. What might call for a tougher demand on the part of the company's own management could be its need for more disaggregated information and for more frequent information updates.

Taking a Japanese company as an example, let us assume that the fundamental analysis has resulted in a limited number of variables. After the multivariate analysis the following have been found the most important: the JPY/EURO exchange rate, the Japanese long-term interest rate, and French producer prices. The sensitivity coefficients for these variables as reported in Table 3 make it possible to translate scenarios into statements about the magnitude of profits or cash flows as well as to filter out the macroeconomic impact on the performance for the latest reporting period. In doing so the outsider shareholder needs information also about the strategy formulation of the firm regarding the current as well as future handling of influences from the identified macro-price variables. Moreover, the sensitivity coefficients form the basis for the risk assessment by the outsider shareholder since they also constitute the exposure coefficients of the company.

The sensitivity measurements in the example express the change in the target variable due to a change in each one of the three identified macroeconomic variables. In accordance with the 
figures in Table 3, a one percentage point increase in the JPY/EURO exchange rate (i.e. a depreciation of the Japanese yen against the euro) leads to a three percent increase in the profit. In this example, the profit is set as the target variable, but the analysis in other cases may refer to sales proceeds, cash flow, etc. The measurement contains competitive aspects and, thus, provides an expression for company's advantage vis-à-vis competitors when the JPY/EURO exchange rate changes.

A common mistake among companies who try to give the most important macroeconomic variables for the company without conducting a comprehensive multivariate analysis, is to point to the exchange rate between the home currency and the currencies of the company's greatest sale and purchasing markets respectively. To look only at the currency distribution in the actual flows often leads to erroneous conclusions. Thus, the major competitor in the company's most important market, in this example the US market, may be a French company with a manufacturing site in France. A comprehensive analysis like the MUST-analysis would, as in this case, probably point to the fact that the Euro is more important than the US dollar.

The information can be given with or without forecasting. Table 3 shows an example in which the result of a comprehensive analysis based on a multivariate identification technique is presented in connection with a forecast in the company discussed above.

\section{Table 3 Reporting according to alternative (4) involving information about the macroeconomic impact on the company}

Forecast: The results will increase next quarter by 15 per cent compared with the preceding quarter. The seasonal effects represent 3 percentage points of that increase. The company's policy is not to work with hedging operations of any kind on external financial markets.

\begin{tabular}{|l|c|c|}
\hline & $\begin{array}{c}\text { The forecast is based on } \\
\text { the following changes in } \\
\text { key variables }\end{array}$ & $\begin{array}{c}\text { Sensitivity coefficients: } \\
\text { one percentage point } \\
\text { increase as compared to } \\
\text { the anticipated change will } \\
\text { impact the profit by }\end{array}$ \\
\hline JPY/EURO & $2 \%$ & $3 \%$ \\
Japanese long-term interest & $2 \%$ & $-2 \%$
\end{tabular}


\begin{tabular}{|l|l|l|} 
rate & & \\
French producer prices & $1 \%$ & $3 \%$ \\
\hline
\end{tabular}

Assume that at the beginning of the quarter an outsider shareholder believes in a different macro-economic scenario from the one on which the company has built its forecast. The information content of Table 3 now allows a re-calculation of forecasted profits in light of the "new" scenario. Excluding macroeconomic influences of 5\% (6\% from the depreciation of the Japanese yen against the euro, $-4 \%$ from the increase of the Japanese long-term interest rate and $3 \%$ from the increase in French prices) and the seasonal effect of 3\%, reveals that the company's own forecast is built upon an assumption of a growth of 7\% (15\%-5\%-3\%).

On the basis of this assumed intrinsic growth, the shareholder mentioned above could now make a new forecast reflecting his or her own macroeconomic scenario. Thus, if the shareholder believes that the JPY/EURO exchange rate will increase by 5 percentage points instead of the assumed 2 percentage points, that the Japanese long-term interest rate will remain unchanged (i.e. a change of zero percentage points), and that French producer prices will increase by 3 percentage points, the shareholder's own forecast will be an adjustment of the company's forecast, such that the result compared with the preceding period increases by $(3+7+15+0+9) \%=34 \%$.

Likewise, and very importantly, at the end of the quarter access to information of the kind presented in Table 3 will allow an analysis of what has happened regarding the sustainable profits, with the latest actual result and the forecasted result as benchmarks. The filtering conducted here is the key issue in the ex post evaluation of corporate performance. It improves the opportunities to make inter-temporal comparisons and to obtain "early warning" signals. Apart from the reporting problem, no management or board of directors should afford not to pay attention to these signals.

Assume that the actual outcome was a $22 \%$ increase in the result relative to the previous period, and given the macroeconomic scenario outlined by the shareholder above. Disregarding the new macroeconomic scenario, management should have got credit for an extra 7\% increase. The implicit but erroneous conclusion would be that the competitiveness of the firm was improving. The $7 \%$ increase might even lead to raises in bonuses, wages and/or 
dividends. But if the change in the macroeconomic environment is adequately allowed for, the conclusions point in the opposite direction. Rather, a result $12 \%$ lower than the improved support provided by the macroeconomic environment would motivate, should call for a detailed examination of the company's performance. The outsider shareholders would now like an explanation of the $12 \%$ decrease - a figure that should be taken as a benchmark. Some explanations may be acceptable, for instance, that a major competitor has been running a campaign during the period. But if there are no acceptable explanations, the shareholders would like to be told how management intends to handle the loss of competitiveness. Instead of enjoying the comfort of a $7 \%$ rise in results, given concrete form in the increases in bonuses, wages and/or dividends mentioned above, the management should now present a plan about how it intends to catch up again in terms of competitiveness by enhancing its support for innovations in the product and production processes.

\section{Concluding Remarks}

The importance of paying attention to the impact of a volatile macroeconomic environment on the competitiveness of the firm should be clear to most managers with experience of the economic turbulence of recent years. An experience that should make most companies willing to carry out analyses according to a comprehensive analysis built on a multivariate framework. Here, it has been argued that inside the firm most of the technical problems related to the measurement of the macroeconomic impact should be resolved.

An open question, however, is whether the results of these analyses will be passed on to the outsider shareholders via corporate external reporting. Measurement problems and the risk of exposing a weakness that can be exploited by competitors are two arguments that will be raised against presenting shareholders with a detailed analysis of the company's development of a multivariate kind offered by e.g. the MUST-analysis.

However, seven compelling factors suggest that within the not-too-distant future there will be a shift of information paradigm. The new reporting practice should have come close to alternative (4) above, implying a complete specification of the most significant macroeconomic variables, of the sensitivity coefficients for these variables estimated within a 
multivariate framework, and of the company's strategy for handling fluctuations in these variables over the past period and in the future. These factors are: 1) the mere presence of IAS 1 (rev. 1997) and similar recommendations; 2) the great increase in competence among financial analysts and the accompanying demand for relevant information for determining the value of the company; 3) the presence of analytical tools like the MUST - analysis, which now allows a proper analysis of the way the company is affected by changes in its macroeconomic environment and the resulting opportunities for adequate information release; 4) the keen and growing interest in shareholder value analysis (SVA, EVA, etc), and the accompanying need to distinguish between what is temporarily created by macroeconomic fluctuations and what is sustainable value; 5) the demand by banks and financial institutions for information that enables an analysis of the sustainability of profits and the resulting determination of the appropriate credit rating of the company; 6) the demand by prestigious international capital market authorities for information in prospectuses in connection with equity and bond issues, on the vulnerability of the issuing company to macroeconomic fluctuations; and, finally, 7) the adoption by the Securities and Exchange Commission of new rules (Regulation FD, effective as of October 2000) against selective disclosure of material information by public companies, and the greater importance today of information about the impact of macroeconomic variables on corporate performance in traditional reporting channels such as annual reports.

While waiting for reporting on the influence of the macroeconomic factors to fall in line with IAS 1 (rev. 1997) alt. 4, outsider shareholders and those engaged in servicing them will attempt as well as they can to conduct something corresponding to a MUST-analysis. The most "ambitious" of these groups - the financial analysts - have of course the technical possibility to carry out the analysis, provided the company reports the most necessary pieces of the information puzzle. If reporting occasions are more frequent, there will be a greater temptation to perform the analysis even without this information. However, without the company's cooperation - in providing the required information pieces or the final result of a comprehensive analysis as part of its external reporting - the prospects are limited for the outsider shareholders and financial analysts to obtain any idea of what is really going on as regards the performance of the company. An interpretation of IAS 1 (rev. 1997) in terms of alternative (4) is the only way to make progress and to give meaning to the two major goals of external reporting. 


\section{References}

Adler, M. and B. Dumas. 1983. "International portfolio choice and corporation finance. A synthesis." Journal of Finance, June, vol. 38, no. 3, pp. 925-984.

Aliber, R. Z. and C. P. Stickney. 1975. “Accounting measures of foreign exchange exposure: The long and short of it." Accounting Review, vol. 50, no. 1, pp. 44-57.

ASC. 1976. Guidance manual on Current Cost Accounting including the Exposure Draft 18. London.

ASC. 1977. Accounting for foreign currency translation, Exposure Draft 21. London.

ASC. 1980. Accounting for foreign currency translation, Exposure Draft 27. London.

ASC. 1983. Foreign currency translation. London.

Barnea, A., J. Ronen, and S. Sadan. 1975. "The implementation of accounting objectives: An application to extraordinary objectives." Accounting Review, vol. 50, no. 1, pp. 58-68.

Beaver, W. H. and M.A.Wolfson. 1982. "Foreign currency translation and changing prices in perfect and complete markets." Journal of Accounting Research, vol. 20, no. 2, pp. 529-542.

Bierman, H., T. Johnson, and S. Peterson.1991. Hedge accounting: An exploratory study of the underlying issues, Norwalk: FASB.

Bromwich, M. 1975. "Individual purchasing power indices and accounting reports." Accounting and Business Research, vol. 5, no. 2, pp. 188-222.

Bromwich, M. 1977. "The general validity of certain current value asset valuation bases." Accounting and Business Research, vol. 7, no. 3, pp. 242-249.

Cahan, S. 1992. "The effect of antitrust investigations on discretionary accruals: A refined test of the political costs hypothesis." Accounting Review, vol. 67, no.1, pp. 77-95.

Capel, J. 1997. “A real option approach to economic exposure management." Journal of International Financial Management and Accounting, vol. 8, pp. 87-113.

CICA. 1978. Translation of foreign currency transactions and foreign currency financial statements. Toronto.

CICA. 1982. Translation of foreign currency transactions and foreign currency financial statements. Toronto.

CICA. 1983. Foreign currency translations, Section 1650. Toronto 
Chambers, R. 1966. Accounting, Evaluation and Economic Behaviour. New Jersey: Prentice Hall.

Cornell, W.B. 1980. "Inflation, relative prices and exchange risk." Financial Management, vol. 9, no. 9, autumn, pp. 30-34.

Craig, R. and P. Walsh. 1989. "Adjustments for extraordinary items in smoothing reported profits of listed Australian companies: Some empirical evidence." Journal of Business Finance and Accounting, vol. 16, no. 2, pp. 229-245.

Dempsey, S. J., H. G. Hunt III, and N. W. Schroeder. 1993. "Earnings management and corporate ownership structure. An examination of extraordinary items reporting." Journal of Business Finance and Accounting, vol. 20, No. 4, pp. 479-500.

Dixit, A. and R.S. Pindyck. 1995. "The option approach to capital investment", Harward Business Review, vol. 64, May/June, pp. 105-115.

Dufey, G and S.L. Srinivasulu. 1983. "The case for corporate management of foreign exchange risk", Financial Management, vol. 12, Winter, pp. 54-62

Durham, J.B. 2001. "Sensitivity analyses of anomalies in developed stock markets", Journal of Banking and Finance, vol. 25, pp. 1503-1541.

Dukes, R. 1978, An empirical investigation of the effects of statement of Financial Accounting Standards no. 8. Financial Accounting Standards Board, Stamford.

Evans P., M. Folks J:r, and M. Jilling. 1978. The impact of statement of Financial Standards No. 8 on the foreign exchange risk management practices of American multinationals. Financial Accounting Standards Board. Stamford.

FASB. 1975. Statement of Financial Accounting Standards No. 8, Accounting for the translation of foreign currency transactions and foreign currency financial statements. Stamford.

FASB. 1981. Statement of Financial Accounting Standards, No. 52, Foreign currency translation. Stamford.

FASB. 1994. Statement of Financial Accounting Standards, No. 119, Disclosure about Derivative Financial Instruments and Fair Value of Financial Instruments. Stamford.

FASB. 1998. Statement of Financial Accounting Standards, No. 133, Accounting for derivative instruments and hedging activities. Stamford.

FASB. 1999. Statement of Financial Accounting Standards, No. 137, Accounting for derivative instruments and hedging activities. Deferral of the effective date of FASB Statement No. 133. Stamford.

Francis, J. 1990. "Accounting for futures contracts and the effect on earnings variability." Accounting Review, vol. 65, no. 4, pp. 891-910. 
Godfrey, J. M. and B. Yee. 1996. "Mining sector currency risk management strategies: Responses to foreign currency accounting regulation." Accounting and Business Research, vol. 26, no. 3, pp. 200-214.

Han, J. C. Y. and S. W. Wang. 1998. "Political costs and earnings management of oil companies during the 1990 Persian Gulf crisis." Accounting Review, vol. 73, no.1, pp. 103-117.

Hekman, C.R. 1985. "A financial model of foreign exchange exposure." Journal of International Business Studies, vol. 16, no. 2, pp. 83-94.

Huefner, R. J., J.E. Ketz, and J. A. Largay III. 1989. "Foreign currency translation and the cash flow statement." Accounting Horizons, vol. 3, no. 1, pp. 66-75.

IASC. 1983. International Accounting Standard 21, Accounting for the Effects of Changes in Foreign Exchange Rates. London.

IASC. 1994. International Accounting Standard 30, Disclosure in the Financial Statements of Banks and Similar Financial Institutions Standard 30. London.

IASC. 1995. International Accounting Standard 32, Financial Instruments: Disclosure and Presentation. London.

IASC. 1997. International Accounting Standard 1, Presentation of Financial Statements. London.

IASC. 1998. International Accounting Standard 39, Financial Instruments: Recognition and Measurement. London.

IFAC. 1999. Enhancing shareholder wealth by better managing business risk. New York: FMAC.

Ijiri, Y. 1975. "Theory of accounting measurement." AAA Research Study 1975, no. 10, Menastra.

Ijiri, Y. 1976. "The price-level restatement and its dual interpretations." Accounting Review, vol. 51, no. 2, pp. 227-243.

Jilling, M. 1978. Foreign exchange risk management in US multinational corporations. Stamford: UMI Research Press.

Jones, J. 1991. "Earnings management during import relief investigations." Journal of Accounting Research, vol. 29, no. 2, pp. 353-367.

Kennedy, C. 1978. "Inflation accounting: retrospect and prospect." Economic Policy Review, pp. 58-64.

Mahdavi, S. and S. Zhou. 1994. "Purchasing power parity in high-inflation countries: Further evidence." Journal of Macroeconomics, vol. 36, no. 5, pp. 403-422. 
Makar, S. D., B. B. Stanko, and T. L. Zeller. 1996. "Foreign currency translation under the temporal rate method." International Advances in Economic Research, vol. 2, no. 4, pp. 444- 454.

McNown, R. and M. S. Wallace. 1989. "National price levels, purchasing power parity and cointregration: A test of four high inflation economies." Journal of International Money and Finance, vol. 8, no. 4, pp. 533-535.

Miltz, D. and P. Sercu. 1993. "Accounting for new financial instruments." Journal of Business Finance and Accounting, vol. 20, no. 2, pp. 275-290.

Oxelheim, L. 1983. "Proposals for new accounting standards for monetary items." Journal of Business Finance and Accounting, vol. 10, no. 2, pp. 257-288.

Oxelheim, L. and C. Wihlborg. 1987. Macroeconomic Uncertainty - International Risks and Opportunities for the Corporation. Chichester and New York: John Wiley and Sons.

Oxelheim, L. and C. Wihlborg. 1991. "Accounting for macroeconomic influences on the firm." Journal of International Financial Management and Accounting, vol. 3, no. 3, pp. 258-252.

Oxelheim, L. and C. Wihlborg. 1997. Managing in the Turbulent World Economy - Corporate Performance and Risk Exposure. Chichester and New York: John Wiley and Sons.

Prakash, P. and S. Sunder. 1979. "The case against separation of current operating profit and holding gains.” Accounting Review, vol. 54, no. 1, pp. 1-22.

Rosenfeld, P. 1972. "Confusion between general price-level restatement and current value accounting." Journal of Accountancy, vol. 140, pp. 63-68.

Samuelson, R. A. 1980. "Should replacement costs changes be included in income." Accounting Review, vol. 55, no. 2, pp. 254-287.

Shank, J., J. Dillard, and R. Murdoch. 1979. Assessing the economic impact of FASB No. 8.. New York: Financial Executives research Foundation.

Schmidt, F. 1930. “The impact of replacement value.” Accounting Review, vol. 5, no. 2, pp. 235-242.

Securities and Exchange Commission. 2000. Regulation FD, Selective Disclosure and Insider Training. Washington.

Staubus, G. 1975. "Price-level accounting: Some unfinished business." Accounting and Business Research, pp. 42-47.

Staubus, G. 1976. "The effects of price-level restatements on earnings." Accounting Review, vol. 51, no. 4, pp. 574-589.

Sterling, R. R. 1975. "Relevant financial reporting in an age of price changes." Journal of Accountancy, vol. 143, no. 1, pp. 42-51. 
Sweeney, H. W. 1927. "Effect of inflation on German accounting." Journal of Accountancy, vol. 95 , no. 3, pp. 180-191.

Vickrey, D. W. 1976. "General price-level adjusted historical cost statements and the ratioscale view." Accounting Review, vol. 51, no. 1, pp. 31-40.

Walsh, P., R. Craig, and F. Clark. 1991. "Big bath accounting" using extraordinary items adjustment: Australian empirical evidence." Journal of Business Finance and Accounting, vol. 18, no. 2, pp. 173-189.

Watts, R. and J. Zimmerman. 1986. "Toward a positive theory of the determination of accounting standards." Accounting Review, vol. 54, no. 2, pp. 112-134.

Westwick, C. A. 1980. "The lessons to be learned from the development of inflation accounting in the UK." Accounting and Business Research, vol. 10, no. 4, pp. 357 373.

Ziebart, D. A. and J-H. Choi. 1998. "The difficulty of achieving economic reality through foreign currency translation." International Journal of Accounting, vol. 33, no. 4, pp. 403-414. 
